\title{
DNA Barcoding to Confirm the Morphological Identification of the Coral Trees (Erythrina spp., Fabaceae) in the Ancient Gardens of Naples (Campania, Italy)
}

\author{
Adriana De Luca ${ }^{1}$ (1) , Giancarlo Sibilio ${ }^{2, *}$ (i), Paolo De Luca ${ }^{2}$ and Emanuele Del Guacchio ${ }^{2}$ \\ 1 Dipartimento di Medicina Veterinaria e Produzioni Animali, Università degli Studi di Napoli Federico II, \\ Via Delpino 1, 80137 Napoli, Italy; adriana.deluca@unina.it \\ 2 Botanical Garden of Naples, Università degli Studi di Napoli Federico II, Via Foria 223, 80139 Napoli, Italy; \\ pdeluca@unina.it (P.D.L.); edelgua@email.it (E.D.G.) \\ * Correspondence: giancarlo.sibilio@unina.it
}

Received: 4 April 2018; Accepted: 4 June 2018; Published: 6 June 2018

\begin{abstract}
The coral trees (genus Erythrina) have been fostering great interest among the botanists and gardeners of Naples, since their arrival in Europe in the second half of the 18th century. Numerous species were present in the royal and private botanical gardens of the region, but their number has decreased today. The purpose of this work was to verify which species occur nowadays in the public areas of Naples and associate them with the historical information about their introduction. The identification was carried out also by molecular methods, by means of sequencing nuclear and chloroplast DNA markers. The comparison of the sequences obtained for the specimens present in Naples with those present in the literature, together with a morphological examination, allowed us to identify with accuracy the species anciently introduced or nowadays cultivated in Naples.
\end{abstract}

Keywords: botanical garden; botanical history; Dehnhardt; DNA barcoding; urban gardens

\section{Introduction}

Genus Erythrina L. (Fabaceae) consists of about 120 species [1-3], mostly trees and shrubs. They are widespread especially in the tropical areas, with the highest number of taxa in America and a smaller number in Africa and Asia [4]. They are most prominently used for ornamental purposes in the warm areas of the world [5], where they become naturalized in some cases [6,7].

In Europe, Erythrina species were originally cultivated mainly in greenhouses. Erythrina abyssinica Lam. arrived in Europe in 1773 following the journeys of J. Bruce in Africa [8]. Erythrina crista-galli L. arrived in Italy in 1772, at the Botanical Garden of Turin, while Erythrina americana Mill. (as Erythrina coralloides DC.) was introduced into the Garden of Lady Durazzo Grimaldi in Genoa in 1805 [9].

In the "Gordon, Dermer, and Thomson" catalog [10], Erythrina herbacea L., Erythrina corallodendron L. and Erythrina picta L. were reported (the latter without indication of the author). In the Baumann Brothers' Catalog [11], published in Germany and France, "Erythrina capensis" (an unidentified species), E. corallodendron L., and Erythrina variegata L. (sub E. picta L.) were available for sale. These catalogues suggest that the plants were present in many collections in Europe at that time. In the second half of the 19th century, at the Botanical Garden of Palermo, the following species were recorded: Erythrina insignis Tod., probably previously cultivated in the nearby Botanical Garden of "Bocca di Falco"; E. crista-galli L. (under the name Erythrina pulcherrima Tod. [12]), probably introduced by seeds from Egypt, and Erythrina arborescens Roxb. (as Erythrina moori Tod. [12]), imported from India. In Palermo, the trees of Erythrina caffra Thunb., planted in the same period, are still living [13]. 
In the Kingdom of Naples, the presence of the genus dates back to 1803, in the Royal Park of Caserta [14]. John Graefer (or Graeffer; Helmstedt, 1746-Bronte, 1802), superintendent of the gardens, reported two species: E. corallodendron and E. picta, either without an author's indication. He very likely obtained these species by the Thomson \& Gordon nurseries, where he had been working earlier $[15,16]$. However, no Erythrina species was reported by Nicola Terracciano [17] in its description of the rare plants growing in the gardens of Caserta, and nowadays this genus is not cultivated there (G.S., pers. obs.).

No escaped individual has been reported for Italy [18] or Campania [19], because of the reproductive difficulties in our climates and of the relative rarity of Erythrina plants in the Italian gardens as well.

This work can be considered as part of a research project on the origin of the floristic diversity of the parks and gardens of Naples [20-26]. The purpose of the present contribution is to verify the occurrence of the genus Erythrina in the main public gardens of Naples and to attempt a reconstruction of the history of their introduction into the city.

\section{Material and Methods}

Historical information was retrieved by consulting the plant catalogues and Indices seminum of the Botanical Garden of Naples, the Royal Garden of Caserta, the Hortus Camaldulensis, and the private botanical garden of the Villa 'Bisignano' [14,17,27-43].

The State Archives of Naples, a relevant source of documents for the history of the cultivated flora of Naples, were investigated as well.

Precious information was obtained from the examination of the dried specimens preserved at the Herbarium Neapolitanum hosted at the Botanical Garden of Naples, where we found pertinent samples in the collections of the eminent botanists Michele Tenore (Napoli, 1780-1861) and Giovanni Gussone (Villamaina 1787-Napoli 1866).

Various species mentioned in the catalogues lack both an author name and an accurate description that would allow species identification. Indeed, in several cases, we found nomina nuda (i.e., names lacking any valid description and therefore not accepted by the 'International Code of Nomenclature for algae, fungi, and plants'), such as "Erythrina pisonaia" [38] or "Erythrina bellengeri" [43], with the impossibility of accurately establishing the botanical species mentioned. Field researches aimed at mapping the presence of Erythrina were carried on in the most important historical parks and gardens of the administrative territory of Naples municipality. The identification was carried out using several floras and monographs $[1,7,44-47]$.

For the purpose of confirming the identity of morphologically dubious or sterile individuals, the leaves from some individuals planted in Naples (see Table 1) were collected and analyzed by molecular techniques (DNA barcoding). In addition, for purposes of comparison and verification, one specimen of E. caffra obtained from South Africa, one specimen of E. americana (once present in the city) originating from Mexico, and one of Erythrina latissima (for which mat $\mathrm{K}$ was not available in the literature), cultivated by seeds collected in the wild (South Africa), were included in the molecular analysis. Among the available molecular markers, nuclear DNA ITS2 and chloroplast DNA $r b c \mathrm{~L}$ and mat $\mathrm{K}$ were chosen for the analysis. The genomic DNAs were isolated from young leaves using the protocol by Doyle \& Doyle [48]; PCR amplifications and sequencing were carried out according to De Luca et. al. [49], with the exception of the PCR conditions, which were as follows: initial denaturation at $95{ }^{\circ} \mathrm{C}$ for $5 \mathrm{~min}$, followed by 35 denaturation cycles at $95{ }^{\circ} \mathrm{C}$ for $45 \mathrm{~s}$, annealing at $55{ }^{\circ} \mathrm{C}$ for $45 \mathrm{~s}$, extension at $72{ }^{\circ} \mathrm{C}$ for $1 \mathrm{~min}$, and a final extension at $72{ }^{\circ} \mathrm{C}$ for $3 \mathrm{~min}$. The raw sequences were analyzed through the Bio Edit software [50], and the identification of sequence barcodes from the samples was conducted using the Basic Local Alignment Search Tool (BLAST (NCBI, Bethesda, MD, USA); [51]).

In order to have a broad picture of the phylogenetic position in the genus of the species presently cultivated in Naples, as well as of E. americana, which was not available in the literature, we carried out a Bayesian analysis as well. 
The selection was carried out by choosing only those taxa for which both matK and $r b c \mathrm{~L}$ sequences were available. ITS2 sequences were not employed, given the small number of Erythrina taxa available in the literature for this marker (overall, less than 10 taxa are available for all three markers). When various accessions for the same taxon were identical in sequence, only one was selected; only Erythrina humeana, for which two different sequences were available for one marker (see Table 2), was employed with two separate accessions. Sequences of Dysolobium grande (Wall. ex Benth.) Prain were employed as outgroups. Such strategy resulted in the selection of the 24 sequences indicated in Table 2. All sequences were aligned by using ClustalW [52] as implemented in Bioedit [50] ver. 9.2. Separate alignments were then reduced to the same length of the regions obtained in this paper. The aligned sequences were then investigated through Bayesian analysis, by using the MrBayes ver. 3.1.2 software [53]. The most likely substitution models were separately computed by using the jModeltest ver. 2.1.7 software [54]. Then, a partitioned matrix was prepared, and four Markov chains (three hot, one cold) were run for 2,000,000 generations, under a GTR + G substitution model [55,56] for matK and a K80 model [57] for $r b c \mathrm{~L}$. The taxonomic treatment followed the monography about the genus Erythrina by Krukoff \& Barneby [1], with the updated nomenclature by the database Tropicos [58].

Table 1. Samples employed in the present study. Legend: ECOB: Erythrina caffra of the Botanical Garden of Naples; ECSA: E. caffra of the Manie van der Schijff Botanical Garden (Southafrica); ECPM: E. caffra of "Piazza Mazzini", Naples; ECVF: E. caffra of "Villa Floridiana", Naples; ECGPV: Erythrina crista-galli of "Piazza Vittoria", Naples; ECGPM: E. crista-galli of "Piazza Municipio", Naples; ECGOB: E. crista-galli of Naples Botanical Garden. The column "Genbank no." indicates the accession number of the literature sequence with which the highest identity was verified.

\begin{tabular}{|c|c|c|c|c|c|}
\hline Code & Taxon & Origin & Identities & Description2 & GenBank no. \\
\hline ECOB & Erythrina caffra & $\begin{array}{l}\text { Botanical Garden, Naples, } \\
\text { Italy (2016) }\end{array}$ & $\begin{array}{c}293 / 313 \\
(94 \%)\end{array}$ & Erythrina velutina & $\begin{array}{l}\text { JX856571 } \\
\text { (ITS2) }\end{array}$ \\
\hline ECSA & Erythrina caffra & $\begin{array}{l}\text { Manie van der Schijff } \\
\text { Botanical Garden, Petroria, } \\
\text { South Africa (2016) }\end{array}$ & $\begin{array}{c}293 / 313 \\
(94 \%)\end{array}$ & Erythrina velutina & $\begin{array}{l}\text { JX856571 } \\
\text { (ITS2) }\end{array}$ \\
\hline ECVF & Erythrina caffra & $\begin{array}{l}\text { Villa Floridiana, Naples, } \\
\text { Italy (2016) }\end{array}$ & $\begin{array}{c}294 / 313 \\
(94 \%)\end{array}$ & Erythrina velutina & $\begin{array}{l}\text { JX856572 } \\
\text { (ITS2) }\end{array}$ \\
\hline ЕСРM & Erythrina caffra & $\begin{array}{l}\text { Piazza Mazzini, Naples, } \\
\text { Italy (2016) }\end{array}$ & $\begin{array}{c}293 / 313 \\
(94 \%)\end{array}$ & Erythrina velutina & $\begin{array}{l}\text { JX856571 } \\
\text { (ITS2) }\end{array}$ \\
\hline ECCPV & $\begin{array}{l}\text { Erytryna } \\
\text { crista-galli }\end{array}$ & $\begin{array}{c}\text { Piazza Vittoria, Naples, } \\
\text { Italy (2016) }\end{array}$ & $\begin{array}{c}311 / 312 \\
(99 \%)\end{array}$ & $\begin{array}{l}\text { Erythrina } \\
\text { crista-galli }\end{array}$ & $\begin{array}{l}\text { FN825780 } \\
\text { (ITS2) }\end{array}$ \\
\hline ECCPM & $\begin{array}{l}\text { Erytryna } \\
\text { crista-galli }\end{array}$ & $\begin{array}{l}\text { Piazza Municipio, Naples, } \\
\text { Italy (2016) }\end{array}$ & $\begin{array}{c}311 / 312 \\
(99 \%)\end{array}$ & $\begin{array}{l}\text { Erythrina } \\
\text { crista-galli }\end{array}$ & $\begin{array}{l}\text { FN825780 } \\
\text { (ITS2) }\end{array}$ \\
\hline ECGOB & $\begin{array}{l}\text { Erytryna } \\
\text { crista-galli }\end{array}$ & $\begin{array}{l}\text { Botanical Garden, Naples, } \\
\text { Italy (2016) }\end{array}$ & $\begin{array}{c}312 / 312 \\
(100 \%)\end{array}$ & $\begin{array}{l}\text { Erythrina } \\
\text { crista-galli }\end{array}$ & $\begin{array}{l}\text { FN825781 } \\
\text { (ITS2) }\end{array}$ \\
\hline ECOB & Erythrina caffra & $\begin{array}{c}\text { Botanical Garden, Naples, } \\
\text { Italy (2016) }\end{array}$ & $\begin{array}{l}497 / 497 \\
(100 \%) \\
\end{array}$ & Erythrina caffra & $\begin{array}{l}\mathrm{JQ} 412236 \\
\text { (matK) }\end{array}$ \\
\hline ECSA & Erythrina caffra & $\begin{array}{c}\text { Manie van der Schijff } \\
\text { Botanical Garden, Petroria, } \\
\text { South Africa (2016) }\end{array}$ & $\begin{array}{l}497 / 497 \\
(100 \%)\end{array}$ & Erythrina caffra & $\begin{array}{l}\text { JQ412236 } \\
\text { (matK) }\end{array}$ \\
\hline ЕСРM & Erythrina caffra & $\begin{array}{c}\text { Villa Floridiana, Naples, } \\
\text { Italy (2016) }\end{array}$ & $\begin{array}{c}496 / 499 \\
(99 \%)\end{array}$ & Erythrina caffra & $\begin{array}{l}\mathrm{JQ} 412236 \\
\text { (matK) }\end{array}$ \\
\hline ECVF & Erythrina caffra & $\begin{array}{l}\text { Piazza Mazzini, Naples, } \\
\text { Italy (2016) }\end{array}$ & $\begin{array}{c}495 / 499 \\
(99 \%)\end{array}$ & Erythrina caffra & $\begin{array}{l}\text { JQ412236 } \\
\text { (matK) }\end{array}$ \\
\hline ECGPV & $\begin{array}{l}\text { Erythrina } \\
\text { crista-galli }\end{array}$ & $\begin{array}{c}\text { Piazza Vittoria, Naples, } \\
\text { Italy (2016) }\end{array}$ & $\begin{array}{c}511 / 514 \\
(99 \%)\end{array}$ & $\begin{array}{l}\text { Erythrina } \\
\text { crista-galli }\end{array}$ & $\begin{array}{l}\mathrm{AY} 386869 \\
(\text { matK) }\end{array}$ \\
\hline ECGPM & $\begin{array}{l}\text { Erythrina } \\
\text { crista-galli }\end{array}$ & $\begin{array}{l}\text { Piazza Municipio, } \\
\text { Naples, Italy }\end{array}$ & $\begin{array}{c}511 / 514 \\
(99 \%)\end{array}$ & $\begin{array}{l}\text { Erythrina } \\
\text { crista-galli }\end{array}$ & $\begin{array}{l}\mathrm{AY} 386869 \\
(\text { matK })\end{array}$ \\
\hline
\end{tabular}


Table 1. Cont.

\begin{tabular}{|c|c|c|c|c|c|}
\hline Code & Taxon & Origin & Identities & Description2 & GenBank no. \\
\hline ECGOB & $\begin{array}{l}\text { Erythrina } \\
\text { crista-galli }\end{array}$ & $\begin{array}{l}\text { Botanical Garden, } \\
\text { Naples, Italy }\end{array}$ & $\begin{array}{c}510 / 514 \\
(99 \%)\end{array}$ & $\begin{array}{l}\text { Erythrina } \\
\text { crista-galli }\end{array}$ & $\begin{array}{c}\mathrm{AY} 386869 \\
(\mathrm{matK})\end{array}$ \\
\hline ECOB & Erythrina caffra & $\begin{array}{l}\text { Botanical Garden, Naples, } \\
\text { Italy (2016) }\end{array}$ & $\begin{array}{c}469 / 469 \\
(100 \%)\end{array}$ & Erythrina caffra & $\begin{array}{l}\mathrm{JQ} 412356 \\
(r b c \mathrm{~L})\end{array}$ \\
\hline ECSA & Erythrina caffra & $\begin{array}{l}\text { Manie van der Schijff } \\
\text { Botanical Garden, Petroria, } \\
\text { South Africa (2016) }\end{array}$ & $\begin{array}{c}469 / 469 \\
(100 \%)\end{array}$ & Erythrina caffra & $\begin{array}{l}\mathrm{JQ} 412356 \\
(r b c \mathrm{~L})\end{array}$ \\
\hline ECPM & Erythrina caffra & $\begin{array}{l}\text { Villa Floridiana, Naples, } \\
\text { Italy (2016) }\end{array}$ & $\begin{array}{c}469 / 469 \\
(100 \%)\end{array}$ & Erythrina caffra & $\begin{array}{l}\text { JQ412356 } \\
(r b c \mathrm{~L})\end{array}$ \\
\hline ECVF & Erythrina caffra & $\begin{array}{c}\text { Piazza Mazzini, } \\
\text { Naples, Italy (2016) }\end{array}$ & $\begin{array}{c}469 / 469 \\
(100 \%)\end{array}$ & Erythrina caffra & $\begin{array}{l}\text { JQ412356 } \\
(r b c \mathrm{~L})\end{array}$ \\
\hline ECGPV & $\begin{array}{l}\text { Erythrina } \\
\text { crista-galli }\end{array}$ & $\begin{array}{c}\text { Piazza Vittoria, } \\
\text { Naples, Italy (2016) }\end{array}$ & $\begin{array}{c}505 / 508 \\
(99 \%)\end{array}$ & $\begin{array}{l}\text { Erythrina } \\
\text { crista-galli }\end{array}$ & $\mathrm{Z} 70170(r b c \mathrm{~L})$ \\
\hline ECGPM & $\begin{array}{l}\text { Erythrina } \\
\text { crista-galli }\end{array}$ & $\begin{array}{l}\text { Piazza Municipio, } \\
\text { Naples, Italy }\end{array}$ & $\begin{array}{c}503 / 508 \\
(99 \%)\end{array}$ & $\begin{array}{l}\text { Erythrina } \\
\text { crista-galli }\end{array}$ & $\mathrm{Z} 70170(r b c \mathrm{~L})$ \\
\hline ECGOB & $\begin{array}{l}\text { Erythrina } \\
\text { crista-galli }\end{array}$ & $\begin{array}{l}\text { Botanical Garden, } \\
\text { Naples, Italy }\end{array}$ & $\begin{array}{c}505 / 508 \\
(99 \%)\end{array}$ & $\begin{array}{l}\text { Erythrina } \\
\text { crista-galli }\end{array}$ & $\mathrm{Z} 70170(r b c \mathrm{~L})$ \\
\hline
\end{tabular}

Table 2. Sequences employed for the Bayesian Inference investigation.

\begin{tabular}{|c|c|c|}
\hline \multirow{2}{*}{ Taxon } & \multicolumn{2}{|c|}{ Genbank Acc. No. } \\
\hline & matK & $r b c \mathrm{~L}$ \\
\hline Erythrina abyssinica Lam. & JX518054 & JX572563 \\
\hline Erythrina americana Mill. & This paper & This paper \\
\hline Erythrina acanthocarpa E.Mey. & KF147397 & KF147471 \\
\hline E. caffra Thunb. & JQ412236 & JQ412356 \\
\hline Erythrina corallodendron $\mathrm{L}$. & KJ012577 & KJ082284 \\
\hline E. crista-galli L. & AY386869 & $\mathrm{Z} 70170$ \\
\hline Erythrina gibbosa Cufod. & JQ587632 & JQ591749 \\
\hline Erythrina herbacea L. & KJ772770 & KJ773492 \\
\hline Erythrina humeana Spreng. (voucher Hosam 00044) & JX495709 & JX571824 \\
\hline E. humeana (voucher OM741) & JF270763 & JF265413 \\
\hline Erythrina lanceolata Standl. & JQ587635 & JQ591753 \\
\hline Erythrina latissima E.Mey. & This paper & JF265414 \\
\hline Erythrina livingstoniana Baker & JX517778 & JX572564 \\
\hline Erythrina lysistemon Hutch & JF270764 & JF265415 \\
\hline Erythrina poeppigiana (Walp.) Skeels & KJ012578 & KJ082285 \\
\hline Erythrina sacleuxii Hua & KX146309 & KU568087 \\
\hline Erythrina sousae Krukoff \& Barneby & EU717411 & EU717270 \\
\hline Erythrina speciosa Andrews & KX816365 & AB045801 \\
\hline Erythrina variegata $\mathrm{L}$. & KU587466 & KU559206 \\
\hline Erythrina velutina Willd. & KY045858 & JX856697 \\
\hline Erythrina vespertilio Benth. & JX850049 & JX856700 \\
\hline Erythrina zeyheri Harv. & JX517714 & JX572565 \\
\hline Dysolobium grande (Wall. ex Benth.) Prain & KX713094 & KX527443 \\
\hline
\end{tabular}

\section{Results}

\subsection{Historical Sources}

The first species to be reported in the Capital was E. herbacea [27], listed in the first catalogue of the ancient botanical garden of Prince Sanseverino di Bisignano in Barra (Napoli 1790-Roma 1865), a suburb of Naples. Later, several Erythrina were introduced by the German gardener and botanist Friedrich Dehnhardt (Bühle, 1787-Napoli, 1870) into the Hortus Camaldulensis, an important private garden [19,25,59]: E. americana (under the synonym Erythrina laeta Dehnh.), E. corallodendron, E. herbacea, and Erythrina speciosa Andrews (by the name 'E. Gräfferi') [41,42]. Unfortunately, both the garden of Camaldoli and that of Prince Bisignano disappeared long time ago. 
The Erythrina species mentioned in the above cited works, as well as those occurring in the Index Seminum and in the catalogue of the Botanical Garden of Naples, are listed in Table 3.

The consultation of the material preserved in the State Archives of Naples attested further introductions of Erythrina species in Naples. An 1833 document reports that F. Dehnhardt proposed the introduction of "E. coralloides" (=E. americana) [60] to adorn the Virgil's Temple at Villa di Chiaja. In a document dated 1839, E. crista-galli, "E. longifolia" (nomen nudum), and E. corallodendron [60] are mentioned among the plants to be used for the flowerbeds of the Villa, which were called "Flora" and "Boschetto". In 1844, a document listing the plants of the Villa Reale reports "Erythrina laurifolia" (=E. crista-galli), [61]. Finally, another document (concerning the years 1856-1859) signed by Dehnhardt is a list of plants to be bought for the villa, generically including Erythrina plants [62]. Further information can be found in Pasquale [63], who cited again "E. laurifolia" (=E. crista-galli) for the first flowerbeds of the Villa and E. corallodendron for the Temple of Virgil. In another article, Pasquale [64] reports that the rare coral tree of E. corallodendron bloomed in the Villa every year.

This latter species is also reported by G. Aiello [65] in describing the Flora of Naples. He writes about outdoor cultivated individuals of E. corallodendron on the Vomero hill.

\subsection{Herbaria Specimens}

In the Herbarium Neapolitanum (herbarium code: NAP), specimens of Erythrina were found in the herbaria of Gussone (Collection "Generale") and in that of Tenore (Appendix A). The morphological examination of this material and the comparison allowed us to state that, at least in some cases, the name E. corallodendron was misapplied by local botanists. In fact, the specimens labelled as E. corallodendron are to be referred instead to E. caffra, while those labelled as E. speciosa represent a variation without taxonomical importance of E. crista-galli. Thus, the herbaria specimens can prove the cultivation, at that time, only of the following species: E. caffra, E. crista-galli, and E. herbacea.

\subsection{Erythrina Plants in the Gardens of Naples at Present}

We located 14 individuals of genus Erythrina cultivated in six public areas of Naples. All the studied Erythrina plants are to be referred only to E. crista-galli or E. caffra. The former species has been mainly identified by the following features: (1) calyx tube shallowly campanulate and glabrous or almost so; (2) keel obliquely lanceolate, longer than half of the standard; (3) standard contracted at the base into a reduced claw; (4) wings minute and much shorter than the keel; (5) inflorescences terminal and leafy or axillary; (6) staminal filaments free only toward the apex (for up to $7 \mathrm{~mm}$ ); (7) corolla scarlet (see Figure 1 for the flower details). The other species, i.e., E. caffra, has been mainly identified by the following features: (1) calyx with cylindrical tube and not-bilabiate in bud but after bilabiate, and pubescent; (2) standard broadly ovate and arcuate; (2) keel petals united by their exterior margin; (3) keel a little shorter than the wings; (4) keel petals not acuminate; (5) wings obtuse; (6) corolla orange-red (see Figure 2 for the flower details). (A) At the Botanical Garden of Naples, an Erythrina tree $10 \mathrm{~m}$ high is present in the collections, in addition to a younger individual originated from it. This plant is locally called the "Dehnhardt tree" and is labelled as "E. laeta Dehnh.". The morphological analysis allowed to identify this tree as E. caffra, and molecular investigations confirmed this as well. In addition, several E. crista-galli individuals are cultivated there. (B) In the area of the Villa Comunale (Villa Reale), there are also six individuals attributable to E. crista-galli (Piazza Vittoria and Piazza dei Martiri) and one belonging to E. caffra, in the exact site cited by Dehnhardt in 1833 [60] and Pasquale [63] under the name "E. corallodendron". (C) In the Royal Park of Capodimonte and at (D) Villa Floridiana, we found two individuals attributable to $E$. caffra but only doubtfully, as they were without flowers at the gathering time. Their identity was confirmed by barcoding. (E) Two individuals of E. crista-galli were planted in the flowerbeds of Piazza Municipio. (F) Finally, a $12 \mathrm{~m}$ tall specimen of E. caffra can be observed in Piazza Mazzini. Table 4 reports the distribution of the sites throughout the city of Naples and their coordinates in UTM (Universal Transverse Mercator) extracted from Google Earth. Figure 3 shows the location on the map of Naples. 
Table 3. Species of Erythrina cultivated in Naples according to the literature. Legend: ${ }^{1}$ by the synonym Erythrina laeta Dehnh.; ${ }^{2}$ as Erythrina insignis Tod.; ${ }^{3}$ as Erythrina Graefferi' (nomen nudum); ${ }^{4}$ as 'E. crista-galli L. var. Andersonii' (nomen nudum); ${ }^{5}$ as 'E. laurifolia' (i.e., E. laurifolia Jacq.); ${ }^{6}$ as 'Erythrina hederaefolia' (i.e., E. hederifolia Spreng.); ${ }^{7}$ as 'Erythrina umbrosa H.B.' (i.e., E. umbrosa Kunth); ${ }^{8}$ as 'E. picta' (i.e., E. picta L.); ${ }^{9}$ as 'Erythrina Pisonaja' (nomen nudum); 10 as 'Erythrina bellengeri' (nomen nudum). ${ }^{*}$ Species nowadays cultivated at the Botanical Garden of Naples.

\begin{tabular}{|c|c|c|c|c|c|c|c|c|c|c|c|c|c|c|c|c|c|c|}
\hline Species & 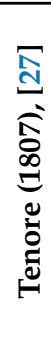 & 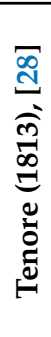 & 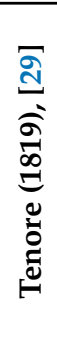 & 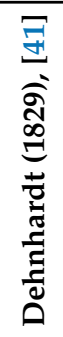 & 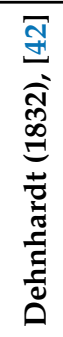 & 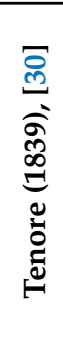 & 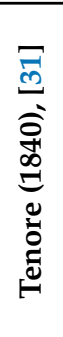 & 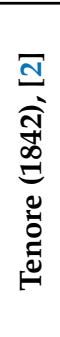 & 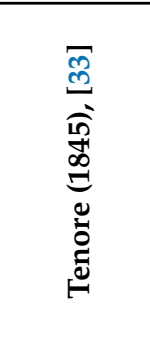 & 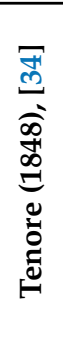 & 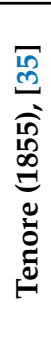 & 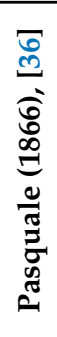 & 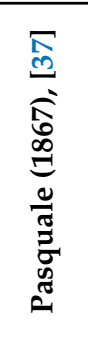 & 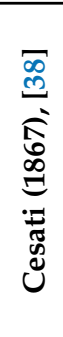 & 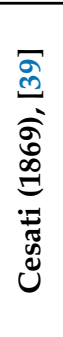 & 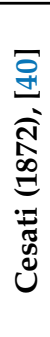 & 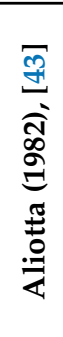 & $\stackrel{*}{\stackrel{*}{\circ}}$ \\
\hline E. americana Mill. & & & & & $x^{1}$ & & & & & & & & & & & & $x^{1}$ & \\
\hline E. caffra Thunb. & & & & & & & & & & & & & $x, x^{2}$ & & & & & $x$ \\
\hline $\begin{array}{l}\text { E. corallodendron } \mathrm{L} \text {. } \\
\text { E. crista-galli } \mathrm{L} \text {. }\end{array}$ & $x$ & $x$ & & $\mathrm{x}$ & $\begin{array}{c}x \\
x^{3}\end{array}$ & $x^{4}$ & $x$ & $x$ & $\begin{array}{c}x \\
x, x^{4}, x^{5}\end{array}$ & $x$ & $x$ & $x$ & $\begin{array}{c}x \\
x, x^{5}\end{array}$ & $x^{5}$ & $x$ & $x$ & $x$ & $x$ \\
\hline E. herbaceaea L. & & $x$ & & $x$ & $x$ & & & & $x^{6}$ & & & & $x$ & & & & & \\
\hline $\begin{array}{c}\text { E. humeana Spreng. } \\
\text { E. mitis Jacq. }\end{array}$ & & & & & & & & & $x^{7}$ & & & & & & & & $x$ & \\
\hline $\begin{array}{c}\text { E. speciosa Andrews } \\
\text { E. variegata L. }\end{array}$ & & & $x$ & $x$ & & & & & $\begin{array}{c}x \\
x^{8}\end{array}$ & & & & $\begin{array}{c}x \\
x^{8}\end{array}$ & & & & & \\
\hline $\begin{array}{l}\text { E. velutina Willd. } \\
\text { Unidentified }\end{array}$ & & & & & & & & & $x$ & & & & $\begin{array}{r}x \\
x^{9}\end{array}$ & & & & $x^{10}$ & \\
\hline
\end{tabular}




\subsection{Genetic Analysis}

The genetic analysis confirmed, after the morphological identification, that all the Erythrina plants at present cultivated in the gardens of Naples are to be referred only to E. crista-galli or E. caffra (the sample of E. caffra of Villa Comunale was considered identical, after systematic analysis, to the other samples of $E$. caffra and, for this reason, not included in the molecular investigation). The percentage of identity between the sequences of E. crista-galli obtained here and the corresponding ITS2, matK, and $r b c \mathrm{~L}$ sequences in the literature for the same species was $99-100 \%$ (Table 1). For E. caffra, the percentage of identity between our sequences and the corresponding mat $\mathrm{K}$ and $r b c \mathrm{~L}$ sequences from the literature also was $99-100 \%$. ITS2 sequences of E. caffra are not available in the literature; the highest percentage of identity of our ITS2 sequences was with Erythrina velutina (94\%, Table 1).

The sequence details are shown in the Appendix B. For the specimen codes, see Table 1, the specimen of E. caffra obtained by the Manie van der Schijff Botanical Garden (Pretoria, South Africa) collections has been used as a control.

The Bayesian analysis was fully convergent at 2,000,000 generations, and all Estimated Sample Sizes were $>>100$. The $95 \%$ maximum clade probability tree (Figure 4 ) showe wide collapses, but our species of interest, i.e., E. caffra and E. crista-galli (and E. americana as well), could be recovered in different clades: E. crista-galli was included in a clade with E. speciosa (which is its sister group), Erythrina poeppigiana, and Erythrina lysistemon (posterior probability p.p. $=0.7866$ ); E. caffra was in a central collapse in the phylogram together with Erythrina humeana (voucher Hosam 00044), whereas E. americana, was included in a clade with E. corallodendron, Erythrina gibbosa, and Erythrina lanceolata, even if with a quite low posterior probability $(p=0.7066)$. E. latissima, for which matK sequence was obtained here, is in a monophyletic group together with E. abyssinica and Erythrina sacleuxii $(p=0.9180)$.

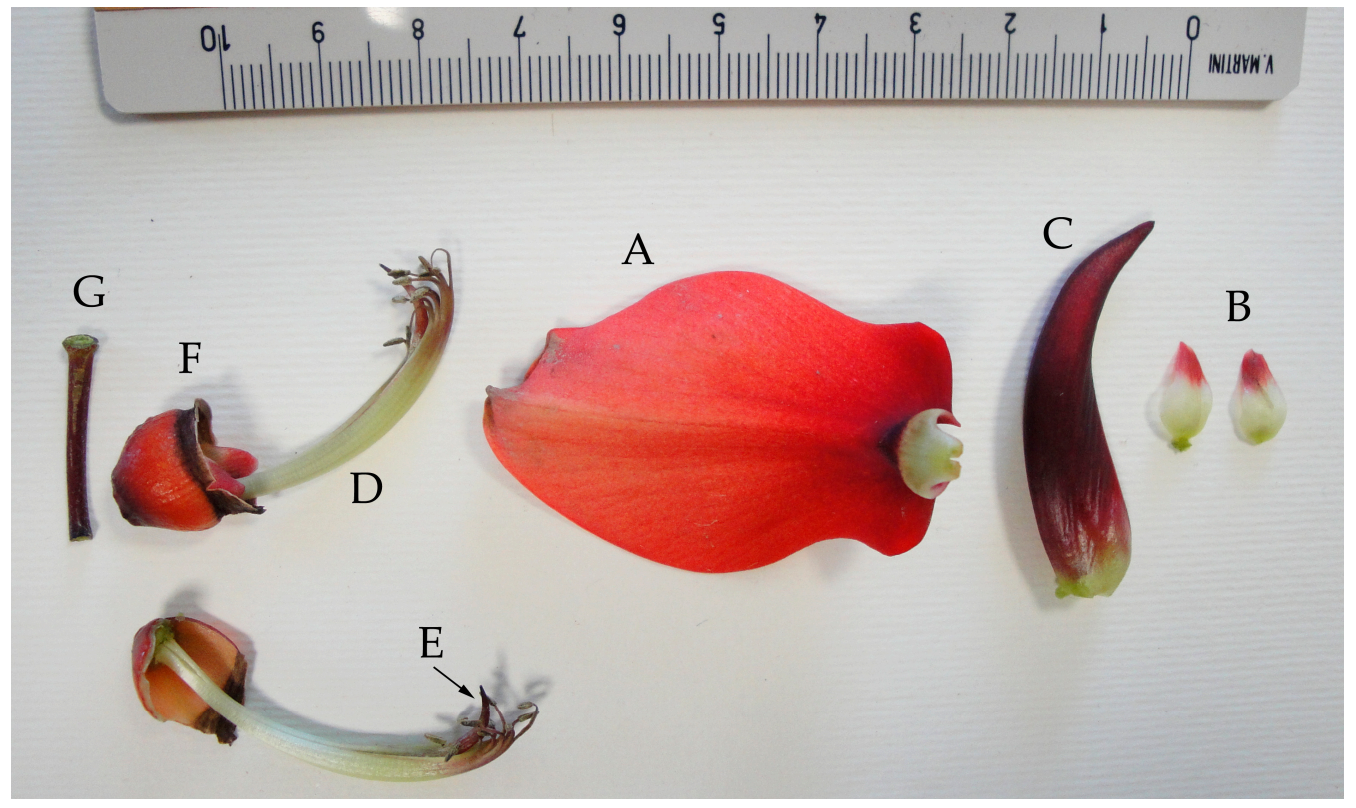

Figure 1. Dissected flowers of Erythrina crista-galli L., collected at Piazza Vittoria, Naples. Legend: (A) standard; (B) wing; (C) keel; (D) staminal tube; (E) style; (F) calyx; (G) pedicel. 


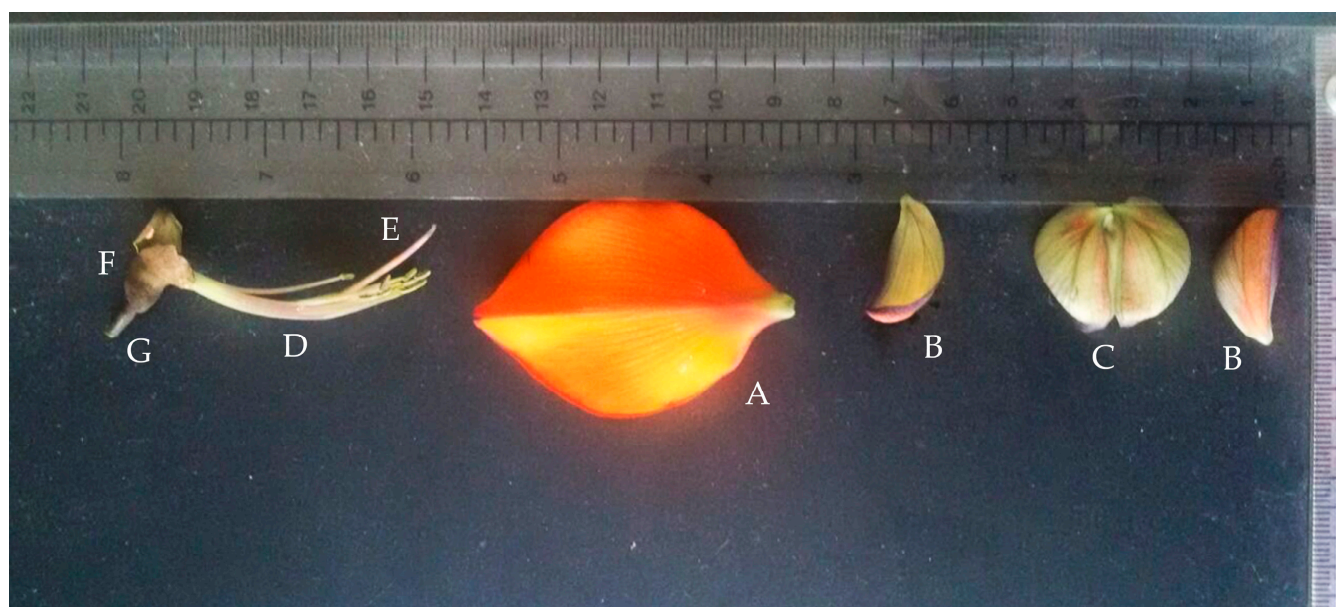

Figure 2. Dissected flower of the "Erythrina of Dehnhardt" (i.e., E. caffra Thunb.) at the Botanical Garden of Naples. Legend: (A) standard; (B) wing; (C) keel; (D) staminal tube; (E) style; (F) calyx; (G) pedicel.

Table 4. Distribution of the sites in the city of Naples and their coordinates in UTM (Universal Transverse Mercator) extracted from Google Earth. See Figure 4 for the location on the map of Naples.

\begin{tabular}{cccc}
\hline E. crista-galli Type Samples & Collection Sites & UTM Coordinates (m) & UTM Coordinates $(\mathbf{m})$ \\
\hline ECGPM & Piazza Municipio & $436,948,76 \mathrm{E}$ & $4,521,091,25 \mathrm{~N}$ \\
ECGPV & Piazza Vittoria & $436,041,31 \mathrm{E}$ & $4,520,442,85 \mathrm{~N}$ \\
ECGOB & Orto Botanico & $437,741,73 \mathrm{E}$ & $4,523,616,01 \mathrm{~N}$ \\
\hline E. caffra Type Samples & Collection Sites & UTM Coordinates (m) & UTM Coordinates (m) \\
\hline ECVC & Villa Comunale & $435,218,25 \mathrm{E}$ & $4,520,535,67 \mathrm{~N}$ \\
ECVF & Villa Floridiana & $435,073,49 \mathrm{E}$ & $4,521,358,05 \mathrm{~N}$ \\
ECPM & Piazza Mazzini & $436,126,69 \mathrm{E}$ & $4,522,527,87 \mathrm{~N}$ \\
ECOB1 & Orto Botanico & $437,828,39 \mathrm{E}$ & $4,523,790,37 \mathrm{~N}$ \\
ECOB2 & Orto Botanico & $437,723,28 \mathrm{E}$ & $4,523,670,84 \mathrm{~N}$ \\
\hline
\end{tabular}

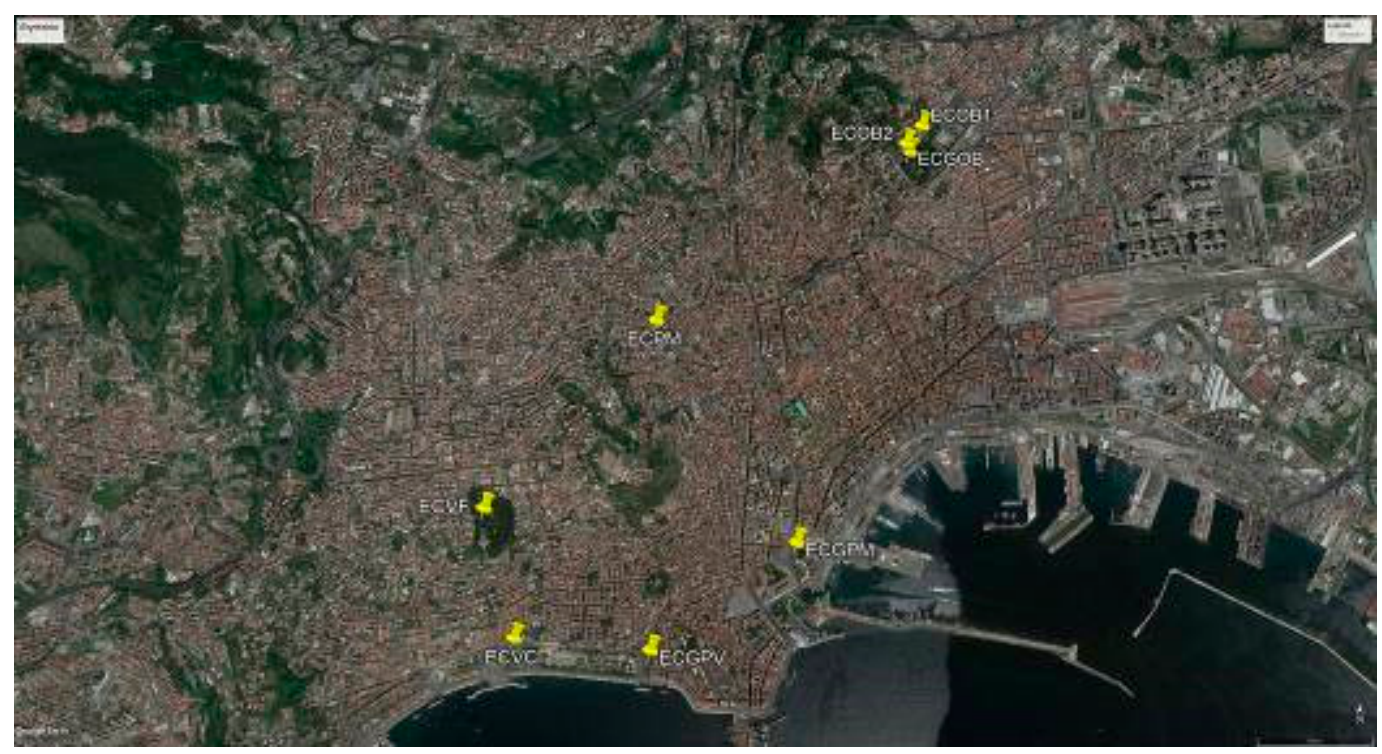

Figure 3. Erythrina specimens growing in the city of Naples, image prepared by using Google Earth cartography. Refer to Table 4 for the legend of the points. 


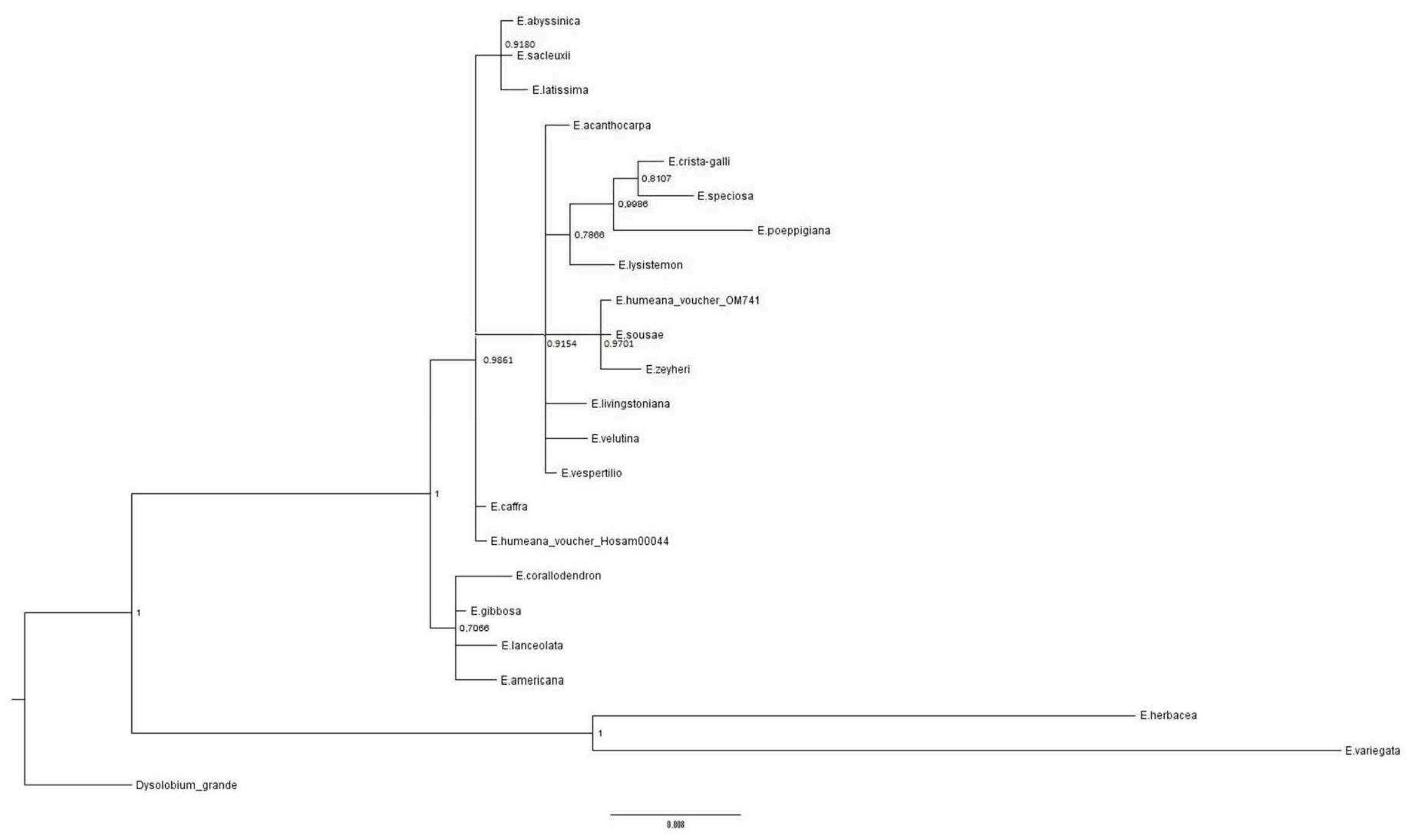

Figure 4. The Bayesian analysis was fully convergent at 2,000,000 generations and all estimated sample sizes were $>>100$. 


\section{Discussion and Conclusions}

Despite only E. crista-galli and E. caffra are found in cultivation in the public areas of Naples nowadays, historical researches indicate the presence of other species, such as E. americana and E. herbacea. It is therefore possible that historical plants, belonging to delicate species, died and were later replaced by more robust ones. This hypothesis is supported by the young age of the plants at Villa Floridiana and Capodimonte. However, a doubt remains on whether E. corallodendron was effectively cultivated in the parks of Naples. The absence of accurate descriptions does not help in this respect. Pasquale [37] cited both E. corallodendron and E. caffra, and these two species obviously can be easily separated during identification. Surprisingly, the examination of historical specimens collected by Gussone and Pasquale at the Villa Reale proves that E. corallodendron was a misapplied name for E. caffra. In addition, the "E. laeta" of the Botanical Garden of Naples (ECOB1 and ECOB2) was found to be actually E. caffra itself, not E. americana, which is the accepted name for E. laeta [25]. Referring now to the nomen nudum "Erythrina andersonii" (also reported as "E. crista-galli var. andersonii"), which was employed by local botanists (Tenore and Gussone) and presumably in horticulture, the examined specimens labelled by that name result to belong to a broad-leaved form E. crista-galli, not worth of taxonomical recognition. Besides, the "Erythrina speciosa", cultivated in the early 19th century in Caserta [14], is E. crista-galli as well, as annotated by Gussone in the labels of his collection. In Naples, only E. crista-galli appears as fully acclimatized, producing intense and vivid blossoms. On the contrary, E. caffra blooms only sporadically over the years and suffers from occasional frosts in the winters. It is indeed much more rarely cultivated than the former species.

This contribution on the historical presence of Erythrina species introduced as ornamental trees in the Kingdom of Naples would have not been possible without the combined usage of morphological identification methods, herbarium and archival research, and DNA barcoding. All these joined techniques, in fact, allowed us to detect first introductions, early misapplication of names, and the present reduction in biodiversity of the cultivated species. A multidisciplinary approach, which includes a mixture of classical and more recent methods in a coherent research strategy, is often the key in reconstructing the history of the introduction of alien plants.

Author Contributions: A.D.L. and P.D.L. conceived and designed the experiments; A.D.L. performed the experiments and wrote the molecular paragraphs; G.S. conducted the bibliographic researches in library and archives, carried out the field researches and wrote the relative parts in the manuscript; P.D.L. and E.D.G. analyzed the data and examined the herbaria specimens; E.D.G. wrote the systematics part.

Funding: This research received no external funding.

Acknowledgments: We thank John Manning and Mario Vàzquez Torres, who provided comparison material, respectively, from South Africa and Mexico. We also thank the curator of the Herbarium Neapolitanum, Roberta Vallariello, for her friendly help. Olga De Castro friendly contributed reagents and analysis tools.

Conflicts of Interest: The authors declare no conflict of interest.

\section{Appendix A}

Selected examined dried specimens. Legend: (NAP-Ten) $=$ Herbarium Neapolitanum, Collection "Tenore"; (NAP-Guss), Herbarium Neapolitanum. Collection "Gussone Generale", s.d. = sine die [without date], s.c. = sine collectore [without collector], s.l. = sine loco [without locality of gathering].

(A) E. caffra Thunb.: (1) Naples at the Villa Reale, April 1867, s.c. (NAP-Guss, sub E. corallodendron); (2) s.l., April 1884, s.c. (NAP-Guss, without species name); (3) Villa Bisignano, s.d., s.c. (NAP-Guss, sub E. corallodendron). (B) E. crista-galli L.: (1) s.l., s.d., s.c. (NAP-Ten, sub E. laurifolia); (2) Botanical Garden of Naples, s.d., s.c. (NAP-Ten, sub E. poianthes); (3) Villa Bisignano, s.d., s.c. (NAP-Guss, sub "E. Andersonii ?"); (4) s.l., s.d., s.c. (NAP-Guss, without species name); (5) Botanical Garden of Naples, s.d., s.c. (Nap-Guss). (C) E. herbacea L.: (1) s.l., s.d., s.c. (NAP-Ten, sub E. hederaefolia Spreng.); (2) Botanical Garden of Naples, 1878, s.c. (NAP-Guss, sub E. hederaefolia Tod.); (3) Garden of the Prince of Bisignano, s.d., s.c. (NAP-Guss). 


\section{Appendix B}

Sequences for ITS2; matK and rbcL. ECOB: E. caffra of Botanical Garden of Naples; ECSA: E. caffra of Manie van der Schijff Botanical Garden (Southafrica); ECPM: E. caffra of "Piazza Mazzini", Naples; ECVF: E. caffra of "Villa Floridiana", Naples; ECGPV: E. crista-galli of "Piazza Vittoria", Naples; ECGPM: E. crista-galli of "Piazza Municipio", Naples; ECGOB: E. crista-galli of Naples Botanical Garden.

ITS2

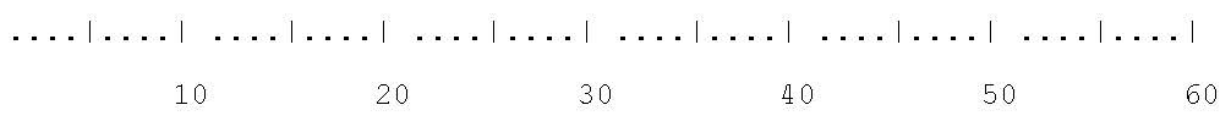

$\mathrm{ECOB}$

ECSA

ECPM

ECVF

ECGPV

ECGPM

ECGOB

ECOB

ECSA

ECPM

ECVF

ECGPV

ECGPM

ECGOB

$\mathrm{ECOB}$

ECSA

ECPM

ECVF

ECGPV

ECGPM

ECGOB

ccgatgeCAt TAGGTTGAGG GCaCGCCTGC CTGGGTGTCa CACaTCGTTA CCCTCCTGCC ccgatgeCAt tAgGtTGAGG GCaCGCCTGC CTGGgtgtCa CACaTCGTtA CCCTCCTGCC GATGCCATTA GGTTGAGGGC ACGCCTGCCT GGGTGTCACA CATCGTTACC CTCCTGCCTC GATGCCATTA GGTTGAGGGC ACGCCTGCCT GGGTGTCACA CATGGTTACC CTCCTGCCTC CcgatgCCAT tAgGtTGAGG GCACGCCTGC CTGGGTGTCA CACATCGTTA CCCTCTTGCC CCGATGCCAT TAGGTTGAGG GCACGCCTGC CTGGGTGTCA CACATCGTTA CCCTCTTGCC CCGATGCCAT TAGGTTGAGG GCACGCCTGC CTGGGTGTCA CACATCGTTA CCCTCCTGCC

$\ldots|\ldots|$
70
TCGtgCAAAt GTCAAAAgAt GTttGcGgAA TGgAgCAAgt AAgGTGCAAG TTGGCTTTCC TCGtGCAAAt GTCAAAAgAt GTTtGCGgAA TGGAGCAAGT AAGGTGCAAG TTGGCTTTCC GTGCAAATGT CAAAAgATGT tTGCCGAATG GAgCAAGTAA GGTGCAAGTT GGCTTTCCCA GTGCAAATGT CAAAAGATGT TTGCCGAATG GAGCAAGTAA GGTGCAAGTT GGCTTTCCCA TCGTGCAAAC GTCAGAAGAT GTTTGTCGAA CGGAGTG--- --GGTGCAAG CTGGCTT-CC TCGTGCAAAC GTCAGAAGAT GTTTGTCGAA CGGAGTG--- --GGTGCAAG CTGGCTT-CC TCGTGCAAAC GTCAGAAGAT GTTTGTCGAA CGGAGTG--- --GGTGCAAG CTGGCTT-CC

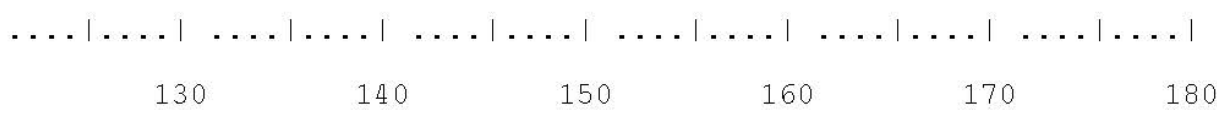

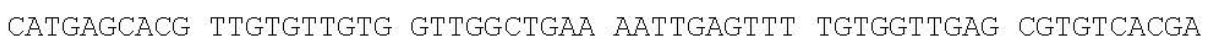

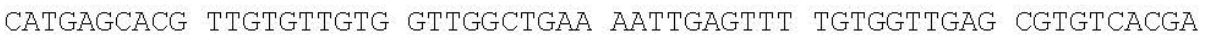

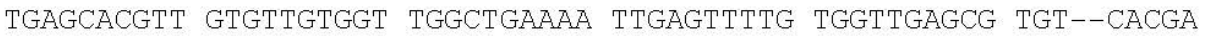
TGAGCACGTT GTGTTGTGGT TGGCTGAAAA TTGAGTTTtG TGGTTGAGCG TGT--CACGA TGTGAGCA-- TTGTCTTGTG GTTGGCTGAA AATtGAgTtT -GCAGTGGAG CGTGTGCCAC TGTGAGCA-- TTGTCTTGTG GTTGGCTGAA AATTGAGTTT -GCAGTGGAG CGTGTGCCAC TGTGAGCA-- TTGTCTTGTG GTTGGCTGAA AATtGAGTTT -GCAGTGGAG CGTGTGCCAC 


$$
\begin{aligned}
& \ldots|\ldots| \ldots|\ldots| \ldots|\ldots| \ldots|\ldots| \ldots|\ldots| \ldots|\ldots| \ldots|\ldots| \\
& \begin{array}{llllll}
190 & 200 & 210 & 220 & 230 & 240
\end{array}
\end{aligned}
$$

$\mathrm{ECOB}$

ECSA

ECPM

ECVF

ECGPV

ECGPM

ECGOB

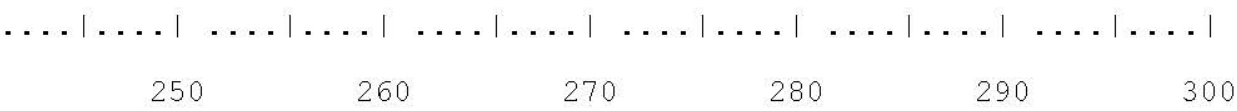

ECOB

ECSA

ECPM

ECVF

ECGPV

ECGPM

ECGOB

$\mathrm{ECOB}$

ECSA

ECPM

ECVF

ECGPV

ECGPM

ECGOB

TAAAATGGTG GATGAGTAGT ATTTGCTCGA GACCAGTTGT GCGCGTCTCA ACCTGTGTTT TAAAATGGTG GATGAGTAGT ATTTGCTCGA GACCAGTTGT GCGCGTCTCA ACCTGTGTTT TAAAATGGTG GATGAgtAgt ATtTGCTCGA GACCAGTTGT GCGCGTCTCA ACCTGTGTTt TAAAATGGTG GATGAGTAGT ATTTGCTCGA GACCAGTTGT GCGCGTCTCA ACCTGTGTTT GATAAAATGG TGGATGAGTT ---TTTGCTC GAGACCAGTT GTGCGCGTCT CAACCTGTGT GATAAAATGG TGGATGAGTT ---TTTGCTC GAGACCAGTT GTGCGCGTCT CAACCTGTGT GATAAAATGG TGGATGAGTT ---TTTGCTC GAGACCAGTT GTGCGCGTCT CAACCTGTGT

GACTCACGAC CCATAAACAC GTCCACGGAC GTTTCACAGC GAGACCTCAG GTCAGGCGGG GACTCACGAC CCATAAACAC GTCCACGGAC GTTTCACAGC GAGACCTCAG GTCAGGCGGG GACTCACGAC CCATA---AA CACGTCCACG GACGTTT--- -CACAGCGAG ACCTCAGGTC GACTCACGAC CCATA---AA CACGTCCACG GACGTTT--- -CACAGCGAG ACCTCAGGTC TTGACTCGTG ACCCATACTG AACACGTCGA CGGACGTTTG TTTCACAGCG AGACCTCAGG TTGACTCGTG ACCCATACTG AACACGTCGA CGGACGTTTG TTTCACAGCG AGACCTCAGG TTGACTCGTG ACCCATACTG AACACGTCGA CGGACGTTTG TTTCACAGCG AGACCTCAGG

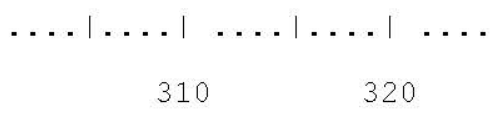

GCTACCCGCT GAGtT........

GCTACCCGCT GAGtT........

AGGCGGGGCT ACCCGCTGAG TT. . AGGCGGGGCT ACCCGCTGAG TT. . TCAGGCGGGG CTACCCGCTG AGTT TCAGGCGGGG CTACCCGCTG AGTT TCAGGCGGGG CTACCCGCTG AGTT 
matK

$$
\begin{gathered}
\ldots|\ldots| \ldots \mid \\
10
\end{gathered}
$$

$\mathrm{ECOB}$

ECSA

ECPM

ECVF

ECGPV

ECGPM

ECGOB

Clustal Co

$\ldots|\ldots| \ldots \mid \ldots$

70

80

90

100

120

ECOB

ECSA

ECPM

ECVF

ECGPV

ECGPM

ECGOB

Clustal Co
ECOB

ECSA

ECPM

ECVF

ECGPV

ECGPM

ECGOB

Clustal Co

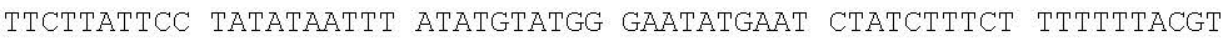
TTCTTATTCC TATATAATt ATATGtATGg GAATATGAAT CTATCTTTCT TTTTTTACGT

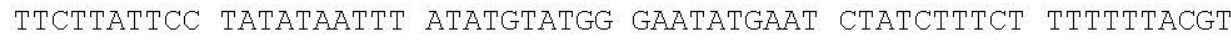

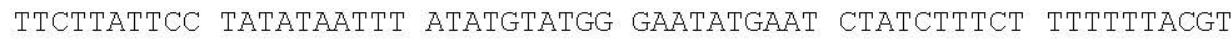
TTCTTGTTCC TATATAATt ATATGTATGg GAATATGAAT CTATCTTTCT TTTtTTACGT TTCTTGTTCC TATATAATT ATATGTATGG GAATATGAAT CTATCTTTCT TTTTTTACGT

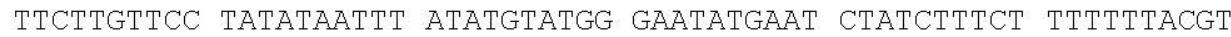
130 140 150 160 170 180 AACAAATCCT CTCAGTTACG GTtAAAATAT tTtCGTGTTT TTtTTGAGCG AATtTTtTTC AACAAATCCT CTCAGTTACG GTTAAAATAT TTTCGTGTTT TTTTTGAGCG AATTTTTTTC AACAAATCCT CTCAGTTACG GTTAAAATAT TTTCGTGTTT TTTTTGAGCG AATTTTTTTC AACAAATCCT CTCAGTTACG GTTAAAATAT TTTCGTGTTT TTTTTGAGCG AATTTTTTTC AACAAATCCT CTCAGTTACG GTTCAAATAT TTTCGTGTTT TTTTTGAGCG AATTTTTTTC AACAAATCCT CTCAGTTACG GTTCAAATAT TTTCGTGTTT TTTTTGAGCG AATTTTTTTC AACAAATCCT CTCAGTTACG GTTCAAATAT TTTCGTGTTT TTTTTGAGCG AATTTTTTT- 


$$
\begin{aligned}
& \ldots|\ldots| \ldots|\ldots| \ldots|\ldots| \ldots|\ldots| \ldots|\ldots| \ldots|\ldots| \ldots|\ldots| \\
& \begin{array}{llllll}
190 & 200 & 210 & 220 & 230 & 240
\end{array}
\end{aligned}
$$

ECOB

ECSA

ECPM

ECVF

ECGPV

ECGPM

ECGOB

Clustal Co

$$
\begin{aligned}
& \ldots|\ldots| \ldots|\ldots| \ldots|\ldots| \ldots|\ldots| \ldots|\ldots| \ldots|\ldots| \ldots|\ldots| \ldots \mid \\
& \begin{array}{lllll}
250 & 260 & 270 & 280 & 290
\end{array}
\end{aligned}
$$

$\mathrm{ECOB}$

tTCTTtAAgG ATCCTTTCAT CCATTATgtT AgAtAtCAAG GAAAATCCAT tTTtGTTTCA

ECSA

ECPM

ECVF

ECGPV

ECGPM

ECGOB

Clustal Co

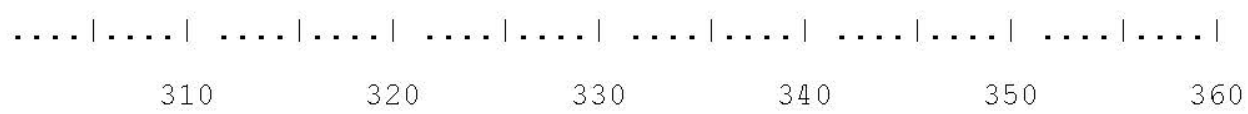

$\mathrm{ECOB}$

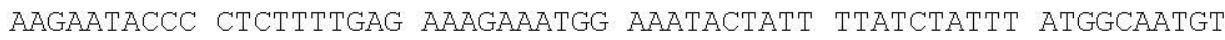

ECSA

ECPM

ECVF

ECGPV

ECGPM

ECGOB

Clustal Co

AAGAATACCC CTCTTTTGAG AAAgAAATGG AAAtACTATT TTATCTATTT ATGGCAATGT

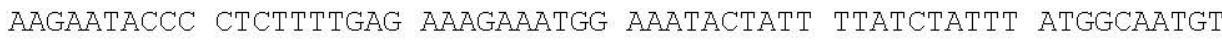

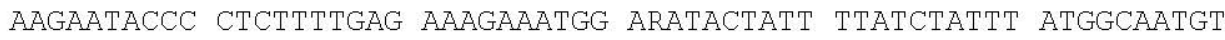
AAGAATACCC CTCTTTTGAT AAAGAAATGG AAATACtATt TTATCTATTT ATGGCAATGT

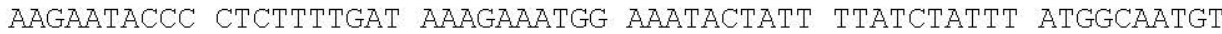
AAGAATACCC CTCTTTTGAT AAAgAAATGg AAATACTATT tTATCTATTT ATGGCAATGt 


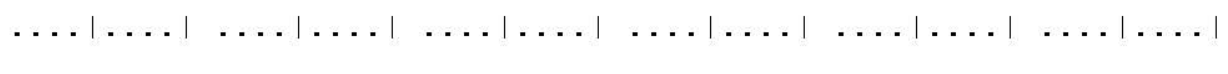

$$
\begin{aligned}
& \begin{array}{lllll}
370 & 380 & 390 & 400 & 410
\end{array}
\end{aligned}
$$

$\mathrm{ECOB}$

ECSA

ECPM

ECVF

ECGPV

ECGPM

ECGOB

Clustal Co
ECOB

ECSA

ECPM

ECVF

ECGPV

ECGPM

ECGOB

Clustal Co

CATTTtgatA TTtgGtCTCG ATCAgAAACA ATCtATCtAA ACCAATTATC CCAGCATTCA CATTTTGATA TTTGGTCTCG ATCAGAAACA ATCtATCtAA ACCAATtATC CCAGCATTCA CATTTTGATA TTTGGTCTCG ATCAGAAACA ATCTATCTAA ACCAATTATC CCAGCATTCA

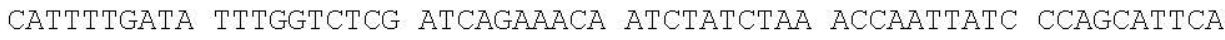
CATtTtGAtA tTtgGtCTCG AtCAGAAACA ATCtATCtAA ACCAATtATC CCAGCATtCA CATtTTGAtA tTtGgtCtCG ATCAGAAACA ATCtATCtAA ACCAATtATC CCAGCATtCA CATTTTGATA TTTGGTCTCG ATCAGAAACA ATCTATCTAA ACCAATTATC CCAGCATTCA

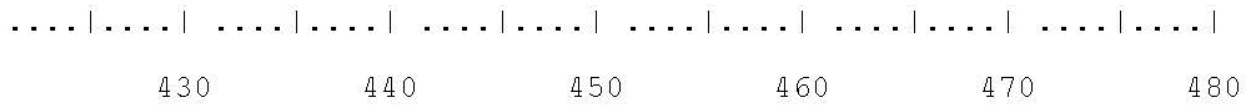

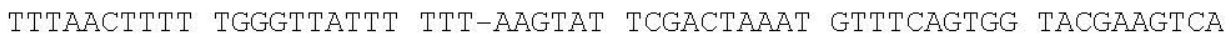

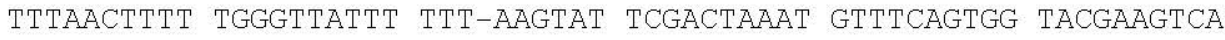

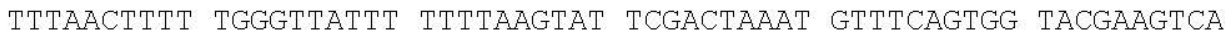

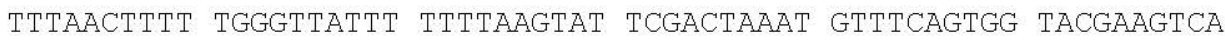
TTTAACTTTT TGGGTTATTT TTTTAAgtAT tCGACTAAAT GTTTCAGTGG TACGAAGTCA TTTAACTTTT TGGGTTATTT TTTTAAGTAT TCGACTAAAT GTTTCAGTGG TACGAAGTCA TTTAACTTT TGGGTTATTT TTTTAAGTAT TCGACTAAAT GTTTCAGTGG TACGAAGTCA $\ldots|\ldots| \ldots|\ldots| \ldots|\ldots| \ldots|\ldots|$
490
500
510

$\begin{array}{ll}\text { ECOB } & \text { AATGTTGCAA AATTCATTT } \\ \text { ECSA } & \text { AATGTTGCAA AATTCATTT } \\ \text { ECPM } & \text { AATGTTGCAA AATTCATTT } \\ \text { ECVF } & \text { AATGTTGCAA AATTCATTT } \\ \text { ECGPV } & \text { AATGTTGCAA AATTCATTT } \\ \text { ECGPM } & \text { AATGTTGCAA AATTCATTT } \\ \text { ECGOB } & \text { AATGTTGCAA AATTCATTT }\end{array}$

Clustal Co 
$r b c L$

$$
\begin{aligned}
& \ldots|\ldots| \ldots|\ldots| \ldots|\ldots| \ldots|\ldots| \ldots|\ldots| \ldots|\ldots| \ldots|\ldots| \\
& \begin{array}{llllll}
10 & 20 & 30 & 40 & 50
\end{array}
\end{aligned}
$$

$\mathrm{ECOB}$

GGCAGCATTT CGAGTAACTC CTCAACCTGG AGTTCCACCT GAAGAAGCAG GTGCCGCGGT

ECSA

GGCAGCATTT CGAGTAACTC CTCAACCTGG AGTTCCACCT GAAGAAGCAG GTGCCGCGGT

ECPM

GGCAGCATTT CGAGTAACTC CTCAACCTGG AGTTCCACCT GAAGAAGCAG GTGCCGCGGT

ECVF

GGCAGCATTT CGAGTAACTC CTCAACCTGG AGTTCCACCT GAAGAAGCAG GTGCCGCGGT

ECGPV

GGCAGCATTT CGAGTAACTC CTCAACCTGG AGTTCCACCT GAAGAAGCAG GTGCCGCGGT

ECGPM

GGCAGCATTT CGAGTAACTC CTCAACCTGG AGTTCCACCT GAAGAAGCAG GTGCCGCGGt

ECGOB

GGCAGCATTT CGAGTAACTC CTCAACCTGG AGTTCCACCT GAAGAAGCAG GTGCCGCGGT

Clustal Co

$$
\begin{aligned}
& \ldots|\ldots| \ldots|\ldots| \ldots|\ldots| \ldots|\ldots| \ldots|\ldots| \ldots|\ldots| \ldots|\ldots| \\
& \begin{array}{llllll}
70 & 80 & 90 & 100 & 110 & 120
\end{array}
\end{aligned}
$$

$\mathrm{ECOB}$

AGCTGCCGAA TCTTCTACTG GTACATGGAC AACTGTGTGG ACTGATGGGC TTACCAGTCT

ECSA

AGCTGCCGAA TCTTCTACTG GTACATGGAC AACTGTGTGG ACTGATGGGC TTACCAGTCT

ECPM AGCTGCCGAA TCTTCTACTG GTACATGGAC AACTGTGTGG ACTGATGGGC TTACCAGTCT

ECVF

ECGPV

ECGPM

ECGOB

Clustal Co AGCTGCCGAA TCTTCTACTG GTACATGGAC AACTGTGTGG ACTGATGGGC TTACCAGTCT

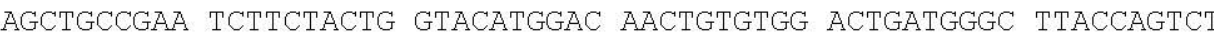
AgCTGCCGAA TCTTCTACTG GTACATGGAC AACTGTGTGG ACTGATGGGC TTACCAGTCT AGCTGCCGAA TCTTCTACTG GTACATGGAC AACTGTGTGG ACTGATGGGC TTACCAGTCT

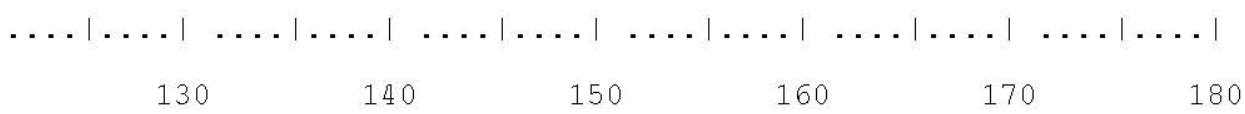

$\mathrm{ECOB}$

TGATCGTTAC AAAGGACGAT GCTACCACAT CGAACCTGTT GCTGGGGAAG AAAATCAATT

ECSA

TGATCGTTAC AAAGGACGAT GCTACCACAT CGAACCTGTT GCTGGGGAAG AAAATCAATT

ECPM

TGATCGTTAC AAAGGACGAT GCTACCACAT CGAACCTGTT GCTGGGGAAG AAAATCAATT

ECVE

ECGPV

TGATCGTTAC AAAGGACGAT GCTACCACAT CGAACCTGTT GCTGGGGAAG AAAATCAATT

ECGPM

TGATCGTTAC AAAGGACGAT GCTACCACAT CGAACCTGTT GCTGGGGAAG AAAATCAATA

TGATCGTTAC AAAGGACGAT GCTACCACAT CGAACCTGTT GCTGGGGAAG AAAATCAATT

ECGOB

TGATCGTTAC AAAGGACGAT GCTACCACAT CGAACCTGTT GCTGGGGAAG AAAATCAATA

Clustal Co 


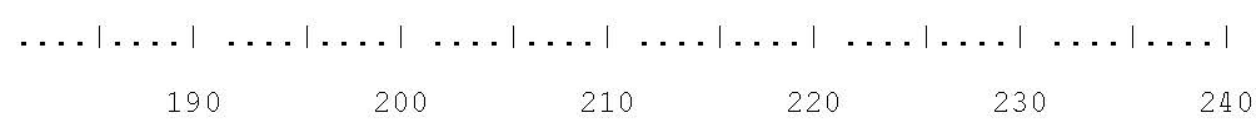

$\mathrm{ECOB}$

TATTGCTTAT GTAGCTTATC CATTAGACCT TtTTGAAGAA GgtTCTGtTA CTAATATGTT

ECSA

TATTGCTTAT GTAGCTTATC CATTAGACCT TTTTGAAGAA GGTTCTGTTA CTAATATGTT

ECPM

ECVF

ECGPV

ECGPM

ECGOB

Clustal Co

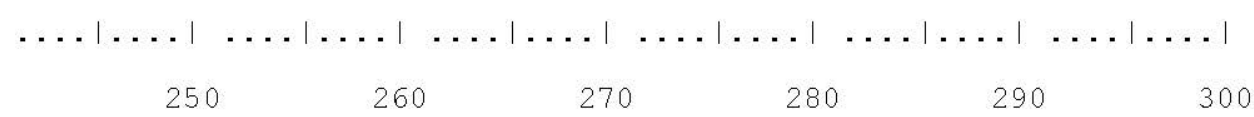

$\mathrm{ECOB}$

TACTTCCATT GTCGGTAATG TATTTGGGTT CAAGGCCCTG CGCGCTCTAC GTCTAGAAGA

ECSA

ECPM

ECVF

ECGPV

ECGPM

ECGOB

Clustal Co

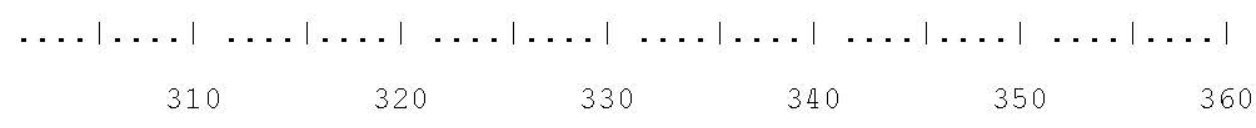

$\mathrm{ECOB}$

ECSA

ECPM

ECVF

ECGPV

ECGPM

ECGOB

TACTTCCATT GTCGGTAATG TATTTGGGTT CAAGGCCCTG CGCGCTCTAC GTCTAGAAGA TACTTCCATT GTCGGTAATG TATTTGGGTT CAAGGCCCTG CGCGCTCTAC GTCTAGAAGA TACTTCCATT GTCGGTAATG TATTTGGGTT CAAGGCCCTG CGCGCTCTAC GTCTAGAAGA TACTTCCATT GTCGGTAATG TATTTGgGtT CAAGGCCCTG CGCGCTCtAC GTCTAGAAGA TACTTCCATT GTCGGTAATG TATTTGGGTT CAAGGCCCTG CGCGCTCTAC GTCTAGAAGA TACTTCCATT GTCGGTAATG TATTTGGGTT CAAGGCCCTG CGCGCTCTAC GTCTAGAAGA

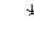




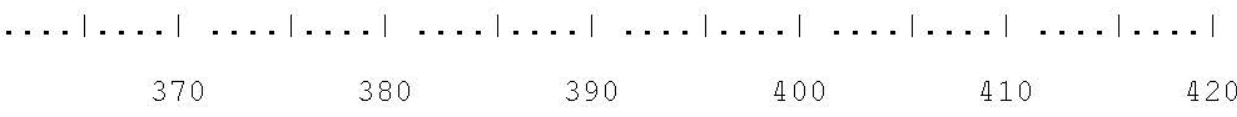

$\mathrm{ECOB}$

ECSA

ECPM

ECVF

ECGPV

ECGPM

ECGOB

Clustal Co

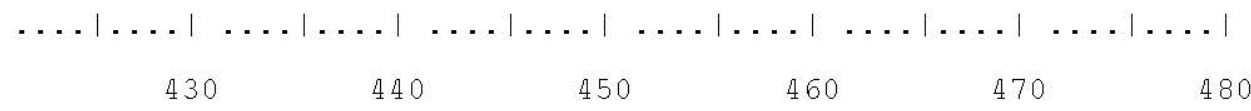

$\mathrm{ECOB}$

ATTGGGGTTA TCCGCTAAGA ATTACGGCAG AGCGGTTTAT GAATGTCTTC GCGGGGGACT

ECSA

ATtGGGGTtA TCCGCTAAgA ATtACGGCAG AGCGgtTTAT GAATGTCTTC GCGGGGGACT

ECPM ATTGGGGTTA TCCGCTAAgA ATtACGgCAg AgCGgtTtAT GAATGTCTTC GCGGGGGACT

ECVE

ECGPV

ECGPM

$\mathrm{ECGOB}$

Clustal Co

$$
\begin{gathered}
\ldots . \ldots|\ldots| \\
490
\end{gathered}
$$

$\mathrm{ECOB}$

CGATTTTACC AAAGATGATG AAAATGTG

ECSA

CGATTTTACC AAAGATGATG AAAATGTG

ECPM

CGATTTTACC AAAGATGATG AAAATGTG

ECVF

CGATTTTACC AAAGATGATG AAAATGTG

ECGPV

TGATTTTACC AAAGATGATG AAAATGTG

ECGPM

CGATTTTACC AAAGATGATG AAAATGTG

ECGOB

TGATTTTACC AAAGATGATG AAAATGTG

Clustal Co

\section{References}

1. Krukoff, B.A.; Barneby, R.C. Conspectus of species of the genus Erythrina. Lloydia 1974, 37, 332-459.

2. ILDIS. International Legume Database \& Information Service. 2015. Available online: Www.ildis.org (accessed on 15 July 2017). 
3. Mabberley, D.J. Mabberley's Plant-Book: A Portable Dictionary of Plants, Their Classification and Uses, 4th ed.; Cambridge University Press: Cambridge, UK, 2017.

4. Russo, R.O.; Baguinon, N.T. Erythrina fusca Loureiro [Internet] Record from Proseabase; Faridah Hanum, I., van der Maesen, L.J.G., Eds.; PROSEA (Plant Resources of South-East Asia) Foundation: Bogor, Indonesia, 1997. Available online: http:/ / www.proseanet.org (accessed on 10 April 2017).

5. Kass, D.L. Erythrina Species-Pantropical Mutipurpose Tree Legumes. In Forage Tree Legumes in Tropical Agriculture; Gutteridfge, R.C., Shelton, M.H., Eds.; Tropical Grassland Society of Australia Inc.: Brisbane Australia, 1998; ISBN 0958567719.

6. Pellow, B.J.; Henwood, M.J.; Carolin, R.C. Flora of the Sidney Region, 5th ed.; Sydney University Press: Sydney, Australia, 2009; ISBN 9781920899301.

7. Nesom, G.L. Key to native and cultivated species of Erythrina (Fabaceae) in the USA and comments on naturalization of E. crista-galli. Phytoneuron 2015, 29, 1-8.

8. Gillet, J.B. The Fruit and Seeds of Erythrina brucei and the Identify of E. abyssinica. Kew Bull. 1962, 15, 425-429. [CrossRef]

9. Maniero, F. Fitocronologia d'Italia; Olschki, L.S.: Florence, Italy, 2000; ISBN 882224897X.

10. A Catalogue of Trees, Shrubs, Plants, Flower, Seeds, E c., Sold by Gordon, Dermer and Thomson, Seed and Nurseryment, at Mile End, Near London; Gale Ecco, Print Editions: Farmington Hills, MI, USA, 2010.

11. Anonymous. De L'Imprimerie de I. H. Decker. Catalogue des Vegetaux en Tout Genre, que les Amateurs du Jardinage, et de L'agriculture Peuvent se Procurer dans L'etablissement des Freres Baumann Proprietaires, Cultivateurs et Pepinieristes a Bollwiller (par Ensisheim) au Departement du Haut-Rhin; Colmar. Biblioteca Nazionale di Napoli: Napoli, Italy, 1819; p. 10.

12. Todaro, A. Hortus Botanicus Panormitanus. Tomus Primus et Secundus (1876-1892); Ristampa analitica a cura dell'Accademia Nazionale di Scienze Lettere e Arti di Palermo: Palermo, Italy, 1993.

13. Domina, G.; Raimondo, F.M. Erythrina viarum Tod. (Leguminosae) from the Palermo Botanical Garden. Webbia 2011, 66, 235-238. [CrossRef]

14. Graefer, J. Synopsis Plantarum Regii Viridarii Casertani. 1803. Available online: www.ortobotanico.unina.it (accessed on 15 October 2017).

15. Coats, A.M. Forgotten Gardeners, II: John Graefer. Gard. Hist. Soc. Newlett. 1972, 16, 4-7. [CrossRef]

16. Desmond, R. Dictionary of British and Irish Botanists and Horticulturists; Taylor \& Francis; The Naturali History Museum: London, UK, 1994.

17. Terracciano, N. Cenno Intorno al Giardino Botanico Della Real Casa in Caserta ed a Certe Piante Rare che vi si Coltivano; Biblioteca dell'Orto Botanico di Napoli: Napoli, Italy, 1876; p. 33.

18. Celesti-Grapow, L.; Pretto, F.; Carli, E.; Blasi, C. (Eds.) Flora Vascolare Alloctona e Invasiva Delle Regioni D'Italia; Casa Editrice Università La Sapienza: Roma, Italy, 2010; p. 208.

19. Del Guacchio, E.; La Valva, V. The non-native vascular flora of Campania (southern Italy). Plant Biosyst. 2017, 152, 767-779. [CrossRef]

20. La Valva, V.; Guarino, C.; De Natale, A.; Cuozzo, V.; Menale, B. La flora del Parco di Capodimonte di Napoli. Delpinoa 1991-1992, 33-34, 143-177.

21. Barone Lumaga, M.R.; Menale, B. L'Hortus Camaldulensis. In AA.VV.: La Botanica a Napoli nel periodo borbonico. Delpinoa 2000, 42, 43-45.

22. Menale, B.; Barone Lumaga, M.R. I giardini botanici napoletani che precedettero l'istituzione del Real Orto Botanico. In AA.VV.: La Botanica a Napoli nel periodo borbonico. Delpinoa 2000, 42, 9-11.

23. Menale, B.; Barone Lumaga, M.R.; De Matteis Tortora, M. Il ruolo dell'Orto Botanico di Napoli nella coltivazione, nello studio e nella diffusione delle specie esotiche durante il periodo tenoreano. In AA.VV.: La Botanica a Napoli nel periodo borbonico. Delpinoa 2000, 42, 35-38.

24. Menale, B.; Di Prisco, C.; Amato, G. La Villa Comunale di Napoli: Cenni storici e analisi della componente vegetale. Delpinoa 2005, 47, 145-154.

25. Del Guacchio, E.; Cennamo, P.; Vàzquez Torres, M.; Menale, B. When art meets taxonomy: Identity of Erythrina laeta (Fabaceae). Phytotaxa 2016, 255, 144-152. [CrossRef]

26. Del Guacchio, E.; Manning, J.; Menale, B.; Caputo, P. A posy of neglected Tritonia species (Iridaceae) from the erstwhile Garden of Camaldoli (Naples, Italy). Taxon 2016, 65, 1409-1414. [CrossRef]

27. Tenore, M. Catalogo del Regal Giardino Botanico di Napoli. Napoli, Stamperia Reale. 1807. Available online: http:/ / www.ortobotanico.unina.it/Catalogo_P/OBN_1807/Catalogo.htm (accessed on 10 October 2017). 
28. Tenore, M. Catalogus Plantarum Horti Regii Neapolitani. Napoli, Appendix Prima. ex Typ. amulliana. 1813. Available online: https:/ /books.google.it (accessed on 10 October 2017).

29. Tenore, M. Catalogus Plantarum Horti Regii Neapolitani. Napoli, Appendix Prima. Editio Altera ex Typ. Diarii Enciclopedici. 1819. Available online: http:/ / www.ortobotanico.unina.it/Catalogo_P/1813ap_altera/ Catalogo.htm (accessed on 10 October 2017).

30. Tenore, M. Index Seminum in Horto Botanico Neapolitano 1839, Collectorum. 1839. Available online: http:/ / www.ortobotanico.unina.it/Catalogo_P/1839/Catalogo3.htm (accessed on 10 October 2017).

31. Tenore, M. Index Seminum in Horto Botanico Neapolitano 1840 Collectorum. 1840. Available online: http:/ / www.ortobotanico.unina.it/Catalogo_P/1840/Catalogo4.htm (accessed on 10 October 2017).

32. Tenore, M. Index Seminum in Regio Horto Botanico Neapolitano 1842 Collectorum. 1842. Available online: http:/ / www.ortobotanico.unina.it/Catalogo_P/altri_cataloghi/1842.pdf (accessed on 15 October 2017).

33. Tenore, M. Catalogo delle piante che si coltivano nel R. Orto Botanico di Napoli. Napoli, Tip. Dell'Aquila di V. Puzziello. 1845. Available online: https:/ / books.google.it/ (accessed on 15 October 2017).

34. Tenore, M. Semina quae in Horto Regio Neapolitano. 1848. Available online: http:/ / www.ortobotanico. unina.it/Catalogo_P/altri_cataloghi/1848.pdf (accessed on 15 October 2017).

35. Tenore, M. Index Seminum quae anno 1855 in Horto R. Botanico Neapolitano. 1855. Available online: http:/ / www.ortobotanico.unina.it/Catalogo_P/altri_cataloghi/1855.pdf (accessed on 15 October 2017).

36. Pasquale, G.A. Index Seminum In Horto R. Neapolitano An. 1866 Collectorum. Napoli-Stabilimento Tipografico Ghio. 1866. Available online: http:/ / www.ortobotanico.unina.it/Catalogo_P/altri_cataloghi/ 1866.pdf (accessed on 15 October 2017).

37. Pasquale, G.A. Catalogo del Real Botanico. Napoli, Tip. Ghio. 1867. Available online: https://books.google. it/ (accessed on 15 October 2017).

38. Cesati, V. Index Seminum in Horto R. Neapolitano an. 1867 Collectorum. Napoli, 1867; Stamperia Govenativa. Available online: http:/ / www.ortobotanico.unina.it/Catalogo_P/altri_cataloghi/1867.pdf (accessed on 10 October 2017).

39. Cesati, V. Index Seminum in Horto R. Neapolitano an. 1869 Collectorum. Napoli, 1869; Stamperia Govenativa. Available online: http:/ / www.ortobotanico.unina.it/Catalogo_P/altri_cataloghi/1869.pdf (accessed on 10 October 2017).

40. Cesati, V. Index Seminum in Horto R. Neapolitano an. 1872 Collectorum. 1872. Available online: http: / / www.ortobotanico.unina.it/Catalogo_P/altri_cataloghi/1872.pdf (accessed on 10 October 2017).

41. Dehnhardt, F. Catalogus Plantarum Horti Camaldulensis; Ortobotanico: Napoli, Italy, 1829. Available online: http://www.ortobotanico.unina.it/Catalogo_P/H_camaldulensis2/Horti_camaldulensis_1829.pdf (accessed on 15 October 2017).

42. Dehnhardt, F. Catalogus Plantarum Horti Camaldulensis, Editio Secunda; Ortobotanico: Napoli, Italy, 1832. Available online: http:/ / www.ortobotanico.unina.it/Catalogo_P/H_camaldulensis/Catalogo.htm (accessed on October 2017).

43. Aliotta, G. Catalogo delle piante coltivate nell'Orto Botanico di Napoli. Supplemento al quaderno $\mathrm{N}^{\circ} 18$ di Agricoltura Ambiente. Edizioni ITPA, Italy. 1985; p. 96.

44. Krukoff, B.A. The American species of Erythrina. Brittonia 1939, 3, 205-337. [CrossRef]

45. Bean, A.R. A taxonomic revision of Erythrina L. (Fabaceae: Faboideae) in Australia. Austrobaileya 2008, 7 , 641-658.

46. Polhill, R.M. Erythrina L. In Flore des Mascareignes; Bosser, J., Cadet, T., Guého, J., Marais, W., Eds.; The Sugar Industry Research Institute: Moka, Mauritius, 1990; Volume 80, pp. 116-119.

47. Sa, R.; Gilbert, M.G. Erythrina Linnaeus. In Flora of China; Wu, Z.Y., Raven, P.H., Hong, D.Y., Eds.; Science Press: Beijing, China; Missouri Botanical Garden Press: St. Louis, MO, USA, 2010; Volume 10, pp. $237-239$.

48. Doyle, J.J.; Doyle, J.L. A rapid DNA isolation procedure for small quantities of fresh leaf tissue. Phytochem. Bull. 1987, 19, 11-15.

49. De Luca, D.; Cennamo, P.; Del Guacchio, E.; Di Novella, R.; Caputo, P. Conservation and genetic characterisation of common bean landraces from Cilento region (southern Italy): High differentiation in spite of low genetic diversity. Genetica 2018, 146, 29-44. [CrossRef] [PubMed]

50. Hall, T.A. BioEdit: A user-friendly biological sequence alignment editor and analysis program for Windows 95/98/NT. Nucleic Acids Symp. 1999, 41, 95-98. 
51. Altschul, S.F.; Madden, T.L.; Schaèffer, A.A.; Zhang, J.; Zhang, Z.; Miller, W.; Lipman, J.D. Gapped BLAST and PSI-BLAST: A new generation of protein database search programs. Nucleic Acids Res. 1997, 25, 3389-3402. [CrossRef] [PubMed]

52. Thompson, J.D.; Higgins, D.G.; Gibson, T.J.; Clustal, W. Improving the sensitivity of progressive multiple sequence alignment through sequence weighting, position-specific gap penalties and weight matrix choice. Nucleic Acids Res. 1994, 22, 4673-4680. [CrossRef] [PubMed]

53. Ronquist, F.; Huelsenbeck, J.P. MrBayes. Bayesian phylogenetic inference under mixed models. Bioinformatics 2003, 19, 1572-1574. [CrossRef] [PubMed]

54. Darriba, D.; Taboada, G.L.; Doallo, R.; Posada, D. jModelTest 2: More models, new heuristics and parallel computing. Nat. Methods 2012, 9, 772. [CrossRef] [PubMed]

55. Lanave, C.; Preparata, G.; Sacconce, C.; Serio, G. A new method for calculating evolutionary substitution rates. J. Mol. Evol. 1984, 20, 86-93. [CrossRef] [PubMed]

56. Tavare, S. Some probabilistic and statistical problems on the analysis of DNA sequences. Lect. Math. Life Sci. 1986, 17, 57-86.

57. Kimura, M. A simple method for estimating evolutionary rates of base substitutions through comparative studies of nucleotide sequences. J. Mol. Evol. 1980, 16, 111-120. [CrossRef] [PubMed]

58. TROPICOS. Missouri Botanical Garden. Available online: http://www.tropicos.org (accessed on 15 July 2017).

59. Agostini, R. Un poco noto Orto Botanico privato Napoletano: L'Hortus Camaldulensis al Vomero. Delpinoa 1962, 3, 407-454.

60. Intendenza di Napoli, III versamento ff. 3079; Archivio di Stato Napoli (ASNA): Naples, Italy, 1839.

61. Intendenza di Napoli, III versamento ff. 3083; Archivio di Stato Napoli (ASNA): Naples, Italy, 1838.

62. Intendenza di Napoli, III versamento ff. 3099; Archivio di Stato Napoli (ASNA): Naples, Italy, 1854-1855.

63. Pasquale, G.A. Una passeggiata per la Villa Reale di Chiaja. Napoli [Naples]: Tipografia F. Azzolino. 1842. Available online: http:/ / www.ortobotanico.unina.it/OBN4/mv/biblioteca/pdf/Pasquale_Villa_Chiaia_ 1842.pdf (accessed on 15 October 2017).

64. Pasquale, G.A. La Bughenvillea spettabile nella Villa Reali di Napoli. In Cosmorama Pittorico Anno X. Milano; SAS: Parma, Italy, 1844; pp. 271-272. Available online: https://books.google.it/ (accessed on 15 October 2017).

65. Aiello, G. Napoli e i Luoghi Celebri Delle Sue Vicinanze; Tip. Gaetano Nobile: Napoli, Italy, 1845; Volume 1. 